University of Nebraska - Lincoln

DigitalCommons@University of Nebraska - Lincoln

Agronomy \& Horticulture -- Faculty Publications

Agronomy and Horticulture Department

2016

\title{
Identification of markers linked to genes for sprouting tolerance (independent of grain color) in hard white winter wheat (HWWW)
}

Juthamas Fakthongphan

University of Nebraska-Lincoln

Guihua Bai

USDA-ARS, guihua.bai@ars.usda.gov

Paul St. Amand

USDA-ARS, paul.stamand@ars.usda.gov

Robert A. Graybosch

USDA-ARS, bob.graybosch@ars.usda.gov

P. Stephen Baenziger

University of Nebraska-Lincoln, pbaenziger1@unl.edu

Follow this and additional works at: https://digitalcommons.unl.edu/agronomyfacpub

Part of the Agricultural Science Commons, Agriculture Commons, Agronomy and Crop Sciences Commons, Botany Commons, Horticulture Commons, Other Plant Sciences Commons, and the Plant Biology Commons

Fakthongphan, Juthamas; Bai, Guihua; St. Amand, Paul; Graybosch, Robert A.; and Baenziger, P. Stephen, "Identification of markers linked to genes for sprouting tolerance (independent of grain color) in hard white winter wheat (HWWW)" (2016). Agronomy \& Horticulture -- Faculty Publications. 1031.

https://digitalcommons.unl.edu/agronomyfacpub/1031

This Article is brought to you for free and open access by the Agronomy and Horticulture Department at DigitalCommons@University of Nebraska - Lincoln. It has been accepted for inclusion in Agronomy \& Horticulture -Faculty Publications by an authorized administrator of DigitalCommons@University of Nebraska - Lincoln. 


\title{
Identification of markers linked to genes for sprouting tolerance (independent of grain color) in hard white winter wheat (HWWW)
}

\author{
Juthamas Fakthongphan ${ }^{1} \cdot$ Guihua Bai $^{2}$ - Paul St. Amand ${ }^{2} \cdot$ R. A. Graybosch ${ }^{3}$. \\ P. S. Baenziger ${ }^{1}$
}

Received: 3 September 2015 / Accepted: 9 November 2015 / Published online: 19 December 2015

(C) Springer-Verlag Berlin Heidelberg (outside the USA) 2015

\begin{abstract}
Key message Hard red wheats can donate genes to hard white wheats for tolerance to preharvest sprouting, the effects are quantitative in nature, and may be tracked with previously described DNA markers.

Abstract Pre-harvest sprouting (PHS) of wheat (Triticum aestivum L.) can negatively impact end-use quality and seed viability at planting. Due to preferences for white over red wheat in international markets, white wheat with PHS tolerance has become increasingly desired for worldwide wheat production. In general, however, red wheat is more tolerant of sprouting than white wheat. The main objective of this study was the identification of PHS tolerance conditioned by genes donated from hard red winter wheat, using markers applicable to the Great Plains hard white wheat gene pool. Three red wheat by white wheat populations, Niobrara/NW99L7068, NE98466/NW99L7068 and Jagalene/NW99L7068 were developed, and white-seeded progenies were analyzed for PHS tolerance and used to identify markers for the trait. In the three populations, marker
\end{abstract}

Communicated by A. Zhang.

Electronic supplementary material The online version of this article (doi:10.1007/s00122-015-2636-4) contains supplementary material, which is available to authorized users.

R. A. Graybosch

Bob.Graybosch@ARS.USDA.GOV

1 Department of Agronomy and Horticulture, University of Nebraska, Lincoln, NE 68583, USA

2 USDA-ARS, Hard Winter Wheat Genetics Research Unit, Kansas State University, Manhattan, KS 66506, USA

3 USDA-ARS, and Department of Agronomy and Horticulture, University of Nebraska, Lincoln, NE 68583, USA loci with significant allelic effects were most commonly located on chromosomes of group 2, 3, 4 and 5, though additional markers were detected across the wheat genome. Chromosome $3 \mathrm{~A}$ was the only chromosome with significant markers in all three populations. Markers were inconsistent across the three populations, and markers linked to tolerance-inducing loci were identified in both tolerant and susceptible parents. Additive effects of marker loci were common. In the present investigation, a wide range of PHS tolerance was observed, even though all lines were fixed for the recently reported positive TaPHS1 allele. PHS tolerance is controlled by additive major gene effects with minor gene effects where variations of minor gene effects were still unclear.

\section{Introduction}

The germination of wheat (Triticum aestivum L.) grain before harvest time is designated pre-harvest sprouting (PHS). The occurrence of PHS in wheat depends upon both the genetic background of the plant and the weather conditions during grain maturation. Warm temperatures and high humidity favor PHS, leading to economically important losses caused by reductions in both grain volume weight and end-use quality, due to the degradation of starch and protein (Flintham 2000). The annual financial loss of Canadian wheat alone from PHS is estimated to exceed $\$ 100$ million (DePauw et al. 2012). Hence, PHS tolerant cultivars are needed in many production zones.

Hard red winter wheats have dominated production in the Great Plains of North America since the beginning of modern agriculture in the region. Hard white winter wheat development and production in the region, however, started in late 1980s. White wheats provide higher flour yield and 
lighter whole wheat flour color compared with red wheats. White wheats have two major markets, namely domestic production for whole wheat breads and as the wheat of choice in many export commercial markets. The Asian wet noodle market, for example, prefers white wheats (Graybosch et al. 2013). To expand wheat marketing potential, developing adapted white wheat cultivars in the United States is necessary, and such wheats require tolerance to PHS.

In cereal crops, seed dormancy and tolerance to PHS are correlated traits, or two manifestations of the same biochemical mechanism (Bewley and Black 1982). Lack of adequate seed dormancy is the major cause for PHS ( $\mathrm{Li}$ et al. 2004). In wheat, PHS tolerance and/or longer seed dormancy are associated with red color pericarp and testa. Wheats with red grain color typically possess greater PHS tolerance than the white wheats (Morris and Paulsen 1992; Groos et al. 2002). The mechanism by which red grain color conditions PHS tolerance is still unclear (Flintham et al. 1999). The association between red grain color and PHS might be explained by a genetic linkage between PHS tolerance and Red genes or it may be due to a pleiotropic effect of the Red genes (Flintham et al. 1999). To insure tolerance to PHS, red wheats typically have been produced in high rainfall environments (Groos et al. 2002). However, genetic diversity for sprouting tolerance exists within both red and white wheats (Wu and Carver 1999) and both tolerant white wheats, and susceptible red wheats, are known.

Evaluation of tolerance to PHS in the field is not precise largely due to the inconsistency of the environmental conditions that favor it (Graybosch et al. 2013) in some geographic regions. Furthermore, environment and genotype $\times$ environment interactions influence tolerance to PHS (Kato et al. 2001). Therefore, more carefully controlled artificial or indirect methods to assess PHS tolerance have been developed. Examples include misting chamber assays, and measurement of starch quality and amylase activity (Clarke et al. 2005; Ross and Bettge 2009). These indirect means are time consuming, labor intensive and difficult to implement as error variances often are high. Germination tests at physiological maturity and germination with the inhibitor abscisic acid (ABA) are alternative approaches (Morris and Paulsen 1989; Wu and Carver 1999).

PHS is a complex trait controlled by quantitative trait loci (QTL) (Fofana et al. 2009; Knox et al. 2012). Given that phenotypic assays are laborious and often error-prone, marker-assisted selection is a desirable method to developing PHS tolerant lines in wheat breeding programs. Markers linked to PHS tolerance QTLs were identified in many prior studies (Kulwal et al. 2005; Mares et al. 2005; Sing et al. 2010, 2012). Kottearachchi et al. (2006) identified a QTL (QPhs-3As) on chromosome 3A using SSR makers. Some white progenies of recombinant inbred lines (RILs) derived from 'Zen'/'Spica' with the 'Zen' allele at QPhs3 As expressed higher dormancy than those with red grain. Liu et al. (2008), using greenhouse-grown Rio Blancoderived populations, identified a QTL (Qhs.pseru-3AS) on chromosome $3 \mathrm{~A}$, which explained over $58 \%$ of phenotypic variation for PHS tolerance. Genetic studies suggest that genes linked with PHS tolerance are mostly located on chromosome 2B, 3A and 4A (Graybosch et al. 2013). Recently, Singh et al. (2014), using simple sequence repeat (SSR) and Diversity Arrays Technology markers (DArT) on Double Haploid (DH) Canadian adapted durum wheats, detected QTL with small effects on chromosome 1A (QPhs.spa-1A), 1B (QPhs.spa-1B), 5B (QPhs.spa-5B), 7A (QPhs.spa-7A) and 7B (QPhs.spa-7B).

Nakamura et al. (2011) studied sequence variation in the promoter region of a wheat gene designated TaMFT, and suggested that the difference in seed dormancy between moderately and highly PHS tolerant genotypes is controlled by this dormancy gene. Liu et al. (2013) using comparative mapping and map-based cloning also isolated this locus (Qphs.pseru.3As) conditioning PHS tolerance. They renamed TaMFT (of Nakamura et al. 2011) to TaPHSI to better reflect the phenotype. Liu et al. found two mutations in TaPHS1 that changed wheat from a PHS tolerant to a susceptible genotype. A GT-to-AT mutation in TaPHSI caused mis-splicing and further led to a premature stop codon that made the transcripts from the gene nonfunctional (Liu et al. 2013). Liu et al. (2013) suggested selection for positive alleles at this locus would be more predictive of PHS tolerance than seed color genes. Moreover, the levels of PHS tolerance of either PHS tolerant or susceptible genotype groups could be further modified by the seed color genes present. McKibbin et al. (2002) determined that mis-splicing of $V p l$ transcripts in wheat led to reduced $V p 1$ protein production and malfunction of the gene, and diminished sprouting tolerance. Many major and minor genes, therefore, can impact tolerance to PHS in diverse genetic backgrounds.

Fakthongphan (2015) used combining ability analysis for both PHS tolerance (measured in a misting chamber) and falling number from field-grown samples, to identify red wheat genotypes, capable of donating genes, independent of seed coat color, that could improve PHS tolerance of hard white wheats. 'Jagalene' consistently demonstrated high general combining ability (GCA) and 'Niobrara' showed moderately consistent GCA. Jagalene and Niobrara, therefore, might serve as sources of additional and previously undescribed genes contributing to PHS tolerance, independent of red seed color. With the need for molecular markers for efficient wheat breeding and the identified PHS tolerance in red wheat parents, additional research is needed to confirm and identify useful markers for improvement of the trait in white wheats. The goal of 
Table 1 Pedigree and the origin of the parental lines

\begin{tabular}{|c|c|c|c|}
\hline Name & Class & Pedigree & Origin \\
\hline Niobrara & HRWW & TAM 105*4/Amigo//Brule & $\begin{array}{l}\text { Nebraska Agricultural Experiment Station and USDA-ARS, Baenziger } \\
\text { et al. } 1996\end{array}$ \\
\hline Jagalene & HRWW & Jagger/Abilene & Syngenta, PVP 200200160 \\
\hline NE98466 & HRWW & KS89H56-4/NE90518 & University of Nebraska \\
\hline NW99L7068 & HWWW & KS84HW1968*RioBlanco/HBY762A//Halt & USDA-ARS, Lincoln, Nebraska \\
\hline
\end{tabular}

$H R W W$ hard red winter wheat, $H W W W$ hard white winter wheat

this study was to identify markers applicable to the Great Plains hard white wheat gene pool. DNA markers were tested to: (1) identify the marker(s) linked to genes from red wheats donating PHS tolerance (2) find the additional minor gene(s) for PHS tolerance and (3) determine the level of the variation in PHS tolerance in populations fixed for the favorable allele at TaPHS1 identified by Liu et al. (2013).

\section{Materials and methods}

\section{Plant materials and field experiment}

Three breeding populations were developed: 'Niobrara/ NW99L7068', 'NE98466/NW99L7068' and 'Jagalene/ NW99L7068'. Niobrara, NE98466 and Jagalene, all red wheats, were mated to the hard white wheat, NW99L7068. Jagalene and Niobrara, as noted above, were selected as potential donors of genes for PHS tolerance. Furthermore, Jagalene previously was described as a PHS tolerant red wheat by additional researchers (Ibrahim et al. 2008). NW99L7068 was used as a susceptible white wheat parent. Origins of these parental lines are presented in Table 1.

Crosses were made in the University of Nebraska Agronomy greenhouse in the spring of 2003 and 2004. The $F_{1}$ generation was increased in the field at Yuma AZ, 2005. $\mathrm{F}_{2}-\mathrm{F}_{5}$ generations were advanced as bulks in the field at Mead, NE from 2006 to 2009. To obtain a pure hard white population, seeds of the $F_{2}$ and subsequent generations were sorted using a prototype version of an automated seed sorting device (Pearson et al. 2008). Subsequent to sorting, only white seeds were planted in each generation. From $\mathrm{F}_{7}$ bulk populations, single-head selections were made and planted in the fall of 2011 as unreplicated $F_{8}$ head-rows with controls replicated and populations blocked in the field at Mead, NE. Advanced generations of 150-160 lines per population were planted as four row plots with controls replicated and populations blocked in the field at Mead and Lincoln, NE in 2013 for the $F_{9}$ generation, and again at Mead for the $F_{10}$ generation in 2014. Jagalene, NE98466,
Niobrara (hard red wheats), 'Antelope', NW99L7068 and 'Nuplains' (hard white wheats) were planted as controls.

\section{Assessment of preharvest sprouting}

At physiological maturity (PM), 40 heads from $\mathrm{F}_{8}$ to $\mathrm{F}_{10}$ generations were snapped for assessment of PHS tolerance via a misting chamber assay. The assay was used to measure Delta Value, a variable estimating tolerance to PHS. Delta Value, the change in head area due to seedling growth after 7 days in misting chambers, was measured using a LiCor (Lincoln, NE, USA) Li-3100C leaf area meter (Fakthongphan 2015; Graybosch et al. 2013). High Delta Values are indicative of low tolerance to PHS.

\section{DNA marker analysis}

Thirty-six primers, previously associated with PHS tolerance, were selected from the literature (Guyomarc'h et al. 2002; Röder et al. 1998; Roy et al. 1999; Somers et al. 2004; Song et al. 2005) and evaluated for polymorphisms among the parents. DNA was extracted from experimental lines at the $\mathrm{F}_{7}$ (2010 plant) generation. Young leaf tissue from a minimum of eight plants was used to isolate DNA with a CTAB (cetyltrimethyl ammonium bromide) method modified from Doyle and Doyle (1987). PCRs were conducted using a total volume of $20 \mu \mathrm{l}$ and contained $10 \mathrm{pmol}$ of each forward and reverse primer. The PCRs also contained $0.2 \mathrm{mM}$ each dNTP, $2 \mathrm{mM} \mathrm{MgCl}{ }_{2}, 1 \mathrm{X}$ Go Taq Buffer supplied by Promega, 0.5 U Go Taq Flexi Polymerase and $100 \mathrm{ng}$ of template DNA in a Bio-Rad DNA Peltier Thermal Cycle. The PCR steps followed Guyomarc'h et al. (2002), Röder et al. (1998), Roy et al. (1999), Somers et al. (2004) and Song et al. (2005). Amplified PCR products were separated on $2 \%$ agarose gels, and stained with ethidium bromide using UV light for visualization.

Twenty-seven primers demonstrating polymorphism in at least one of the three populations, as listed in Supplementary Materials, were selected for further analyses. All primers are simple sequence repeat (SSR) except those with the prefix "MST" were sequence-tagged sites (STS). DNA extraction, PCR preparation and amplification 
Table 2 Analysis of variance of tolerance to preharvest sprouting (Delta Value) from control cultivars grown at four Nebraska environments 2012-2014

\begin{tabular}{lccccc}
\hline Source & DF & Type III SS & Mean square & $F$ value & $\operatorname{Pr}>F$ \\
\hline Control & 5 & 91,541 & 18,308 & 16.58 & $<0.0001$ \\
Error & 17 & 18,443 & 1104 & \\
Error: $0.8165 \times$ MS $($ env $\times$ control) & $+0.1835 \times$ MS (error) & & \\
Environment & 3 & 15,296 & 5098 & 2.14 & 0.133 \\
Error & 17 & 39,706 & 2377 & \\
Error: $0.7704 \times$ MS $($ rep $($ env $))+$ & $0.9568 \times$ MS (control $\times$ env) $-0.72728 \times$ MS (error) & \\
Rep (environment) & 8 & 14,330 & 1791 & 5.69 & $<0.0001$ \\
Environment $\times$ control & 15 & 19,228 & 1281 & 4.07 & $<0.0001$ \\
Error: MS (error) & 328 & 103,250 & 314 & & \\
\hline
\end{tabular}

Table 3 Mean and std error of control for tolerance to preharvest sprouting (Delta Value) from control cultivars grown at four Nebraska environments 2012-2014

\begin{tabular}{|c|c|c|c|c|c|}
\hline \multirow[t]{2}{*}{ Cultivar } & \multicolumn{5}{|c|}{ Mean \pm std err } \\
\hline & MD12 & MD13 & LNK13 & MD14 & $\begin{array}{l}\text { Grand } \\
\text { mean }\end{array}$ \\
\hline \multicolumn{6}{|l|}{ White wheats } \\
\hline Antelope & $52.2 \pm 6.7^{\mathrm{a}}$ & $75.1 \pm 7.2$ & $79.1 \pm 10.9$ & $48.9 \pm 4.2$ & $57.2 \pm 3.4$ \\
\hline Nuplains & $22.9 \pm 6$ & $40.9 \pm 2$ & $54.9 \pm 6.8$ & $53.0 \pm 2.2$ & $45.2 \pm 2.5$ \\
\hline NW99L7068 & $64.7 \pm 6.8$ & $98 \pm 12.7$ & $79.5 \pm 8$ & $59.9 \pm 2.9$ & $68.8 \pm 3.2$ \\
\hline \multicolumn{6}{|l|}{ Red wheats } \\
\hline Jagalene & $18.4 \pm 1.7$ & $16.0 \pm 1.5$ & $23.3 \pm 5.6$ & $19.4 \pm 2.1$ & $19.4 \pm 1.6$ \\
\hline NE98466 & $32.0 \pm 5.4$ & $44.8 \pm 5.5$ & $39.0 \pm 3.8$ & $22.4 \pm 2.8$ & $29.1 \pm 2.3$ \\
\hline Niobrara & $18.4 \pm 6.8$ & $33.2 \pm 3.7$ & $42.9 \pm 6.7$ & $29.3 \pm 2.4$ & $31.4 \pm 2$ \\
\hline
\end{tabular}

${ }^{\text {a }}$ Low Delta Values represent high tolerance to PHS followed Graybosch et al. (2013). Fluorescent PCR fragment products were separated and detected using an ABI Prism 3730 DNA sequencer (http://www.appliedbiosystems.com) and peak data were extracted using GeneMarker version 1.95 (SoftGenetics.com). All lines of all three populations were also genotyped using the SNP markers for tolerant and susceptible alleles at TaPHS1, as described by Liu et al. (2013). No polymorphism at this locus was detected, and all lines were found to carry the "tolerant" allele. MapDisto Genetics Software version 1.7 was used to develop genetic maps in each population and establish chromosomal locations, when possible. LOD minimum 3, r-maximum or d-maximum 0.3 and minimum $10 \%$ of missing data were employed (Lorieux 2012).

\section{Statistical analysis}

PC-SAS software version 9.2 (SAS Institute Inc., Car, NC, USA) was used for all statistical computations. In this study, genotypes (marker alleles) and entry (genotype) were considered fixed effects. Environments and the interaction between genotypes and environments were random effects. A separate analysis of wheat control genotypes was conducted. Analysis of variance (ANOVA), using SAS PROC GLM, was used to evaluate the source of variation for tolerance of PHS among controls. Mean and standard errors of Delta Values were calculated. The least significant difference (LSD) from the controls was calculated and used to compare Delta Values of lines in the three breeding populations.

Mean, standard error, minimum and maximum Delta Values for the three populations were calculated individually. PROC GLM was used to evaluate sources of variation for PHS tolerance, separately, within each population. Markers, environments and interaction between these variables were included in the model. Only confirmed homogeneous and homozygous lines were used for these analyses. Marker alleles (genotypes) were treated as fixed effects, the interaction between markers and environments were considered a random effect. For those loci displaying significant differences by ANOVA, mean and standard error of Delta Value were calculated separately for each locus within each population. Finally, when sample sizes were adequate, two-gene models were evaluated, again separately for each population, using all combinations of unlinked markers demonstrating significant genotypic effects at $P<0.10$. 
Table 4 Mean and std error of tolerance to preharvest sprouting (Delta Value) in three populations of red and white winter wheats

\begin{tabular}{lllllr}
\hline Population & \multicolumn{6}{l}{ Delta Value } & & & \\
\cline { 2 - 6 } & Mean $^{\mathrm{a}}$ & $n$ & Std. err & Min & Max \\
\hline Niobrara/NW99L7068 & 50.4 & 156 & 1.0 & 24.9 & 99.4 \\
NE98466/NW99L7068 & 59.8 & 160 & 1.1 & 27.4 & 113.5 \\
Jagalene/NW99L7068 & 64.4 & 160 & 1.1 & 29.5 & 127.5 \\
\hline
\end{tabular}

Higher mean DV is indicative of lower tolerance to PHS

${ }^{\text {a }}$ Means from 4 environments; Mead 2012, Mead 2013, Lincoln 2013, Mead 2014, NE, USA

\section{Results}

Significant variation in PHS tolerance, as measured by Delta Value, due to environment, genotype and their interaction, was observed for the control genotypes (Table 2). Means by environments, grand mean and standard error of control cultivars are presented in Table 3. Among white wheats, Delta Values ranged from a low 45.2 (Nuplains) to a high of 68.8 (NW99L7068). Delta Values ranged from a low 19.4 (Jagalene) to a high of 29.1 (NE98466) among the red wheat controls. The hard red wheats had significantly higher tolerance to PHS (lower Delta Values) than the hard white wheat controls. Again, lower Delta Values are indicative of greater tolerance to PHS.

Table 4 presents mean and standard error of PHS tolerance in the three white wheat breeding populations. Mean Delta Values of individual lines from the same three populations are displayed in the histograms in Fig. 1. Observed Delta Value means of individual lines ranged from 24.9 to 99.4 (Niobrara/NW99L7068), from 27.4 to 113.5 (NE98466/NW99L7068) and from 29.5 to 127.5 (Jagalene/NW99L7068). Parental Delta Value means were 31.4 (Niobrara), 29.1 (NE98466), 19.4 (Jagalene) and 68.8 (NW99L7068). Progenies from all three populations showed wider ranges of Delta Value than their parents. Based on the LSD, 16.8, 20.1 and $23.1 \%$ of lines were not significantly different in tolerance to PHS than the red parent in Niobrara/NW99L7068, NE98466/NW99L7068 and Jagalene/NW99L7068, respectively. Even though all entries of all three populations were fixed for the "favorable" allele at TaPHSI on chromosome 3AS, identified by Liu et al. (2013), a wide range of response in PHS tolerance still was observed.

The mapped chromosome locations based on both GrainGenes (http://wheat.pw.usda.gov/GG3) and confirmed in the present study are shown in Tables 5, 6 and 7, along with analyses of variance for each population. Significant environmental variation was observed for nearly all polymorphic markers in all three populations. In Niobrara/NW99L7068,
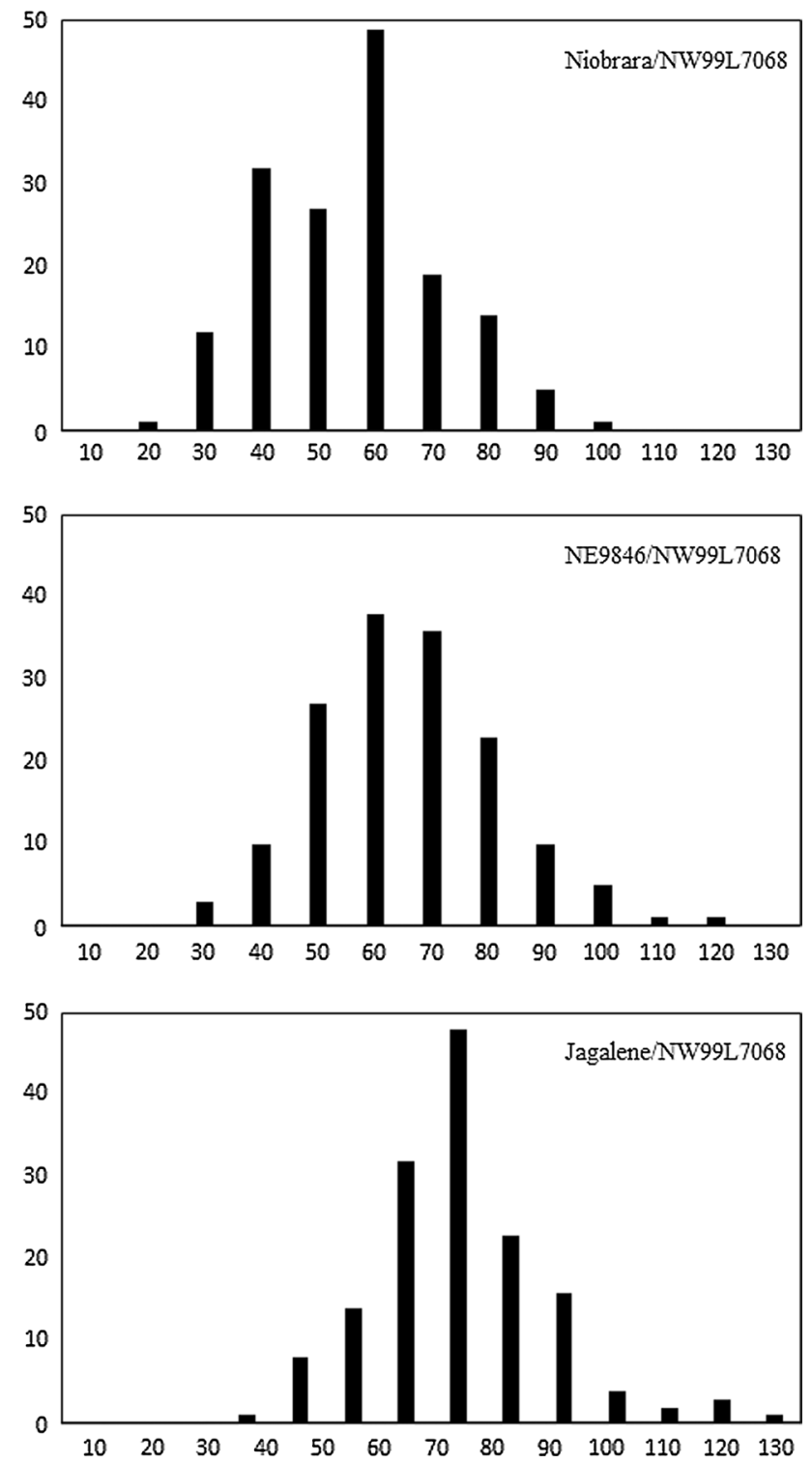

Fig. 1 Histograms of Delta Value of lines in three breeding populations of hard white winter wheat; LSD $=13.8$; Parental lines: Nio $=$ Niobrara, NW $=$ NW99L7068, NE $=$ NE98466, Jag $=$ Jagalene

significant effects due to markers (allele) at $P<0.10$ were observed for Xbarc10, Xbarc77 and Xwmc594; in NE98466/ NW99L7068 for Xbar59, Xbarc105, Xcfd10 and Xgwm132; in Jagalene/NW99L7068 for Xbarc59, Xgwm155, Xgwm261, Xgwm371and Xgwmc428. Markers with significant effects due to genotype (allele) were found on several chromosomes, though significant markers on chromosome 3A were most frequent. Allelic effects of the observed significant markers are given in Table 8. The interaction between environment and marker was rarely significant in any of the three populations (Tables 5, 6, 7). 
Table 5 Mean square from analysis of variance of putative markers for preharvest sprouting tolerance (Delta Value) in population 1 (Niobrara/ NW99L7068)

\begin{tabular}{|c|c|c|c|c|c|c|}
\hline \multirow[t]{2}{*}{ Marker } & \multirow[t]{2}{*}{ Chromosome $^{\mathrm{b}}$} & \multicolumn{5}{|l|}{ Mean square ${ }^{\mathrm{a}}$} \\
\hline & & Environment & Genotype & Entry (genotype) & Genotype $\times$ environment & Error \\
\hline Xbarc10 & $2 \mathrm{~B}^{\mathrm{c}}, 4 \mathrm{~B}^{\mathrm{c}}, 5 \mathrm{~A}^{\mathrm{c}}, 7 \mathrm{~B}^{\mathrm{c}}$ & $4079 * * *$ & $4450 * * *$ & $670 * * *$ & 47.5 & 345 \\
\hline Xbarc57 & $3 \mathrm{~A}^{\mathrm{c}}$ & $7481 * * *$ & $345^{*}$ & $883 * * *$ & 155.1 & 403 \\
\hline Xbarc77 & $3 \mathrm{~B}^{\mathrm{c}}$ & $12,298^{*}$ & $3392 * *$ & $815 * * *$ & $389^{*}$ & 422 \\
\hline Xbarc59 & $2 \mathrm{D}^{\mathrm{c}}, 5 \mathrm{~B}^{\mathrm{c}}$ & $20,409 * * *$ & $1080^{*}$ & $845 * * *$ & $600 * *$ & 417 \\
\hline Xbarc321 & $3 \mathrm{~A}^{\mathrm{d}}, 3 \mathrm{D}^{\mathrm{c}}$ & $17,566 * * *$ & $2983^{*}$ & $810 * * *$ & $914.1 * *$ & 407 \\
\hline Xgwm132 & $6 \mathrm{~B}^{\mathrm{c}}, 6 \mathrm{D}^{\mathrm{c}}$ & $9538 * * *$ & 756 & $762 * * *$ & 543 & 403 \\
\hline Xgwm261 & $2 \mathrm{D}^{\mathrm{c}}$ & $17,932 * * *$ & $2674^{*}$ & $786 * * *$ & $1343 * * *$ & 417 \\
\hline Xgwm429 & $2 \mathrm{~B}^{\mathrm{c}}$ & $12,614 * * *$ & $2239^{*}$ & $792 * * *$ & $982 * *$ & 407 \\
\hline Xwmc48 & $4 \mathrm{~A}^{\mathrm{c}}, 4 \mathrm{~B}^{\mathrm{c}}$ & $16,058 * * *$ & 320 & $826 * * *$ & 334 & 394 \\
\hline Xwms319 & $2 \mathrm{~B}^{\mathrm{c}, \mathrm{c}}, 7 \mathrm{~A}^{\mathrm{c}}$ & $5389 *$ & 471 & $704 * * *$ & $673^{*}$ & 384 \\
\hline Xwmc428 & $3 \mathrm{~A}^{\mathrm{c}}$ & $15,431 * * *$ & $1722 *$ & $864 * * *$ & $680^{*}$ & 407 \\
\hline Xwmc594 & $3 \mathrm{~A}^{\mathrm{c}, \mathrm{d}}$ & $11,718 * *$ & $8552 * *$ & $772 * * *$ & $1211^{* * *}$ & 421 \\
\hline Xwms429 & $2 \mathrm{~B}^{\mathrm{c}, \mathrm{d}}$ & $11,220 * *$ & $1495^{*}$ & $871 * * *$ & $791^{*}$ & 413 \\
\hline
\end{tabular}

***,**, * Significant effects or difference observed at $P<0.05, P<0.10, P<0.25$ level

${ }^{\text {a }} F$ value was calculated using different error term in the Type 3 analysis of PROC MIXED Delta Value from 4 environments; Mead 2012, Mead 2013, Lincoln 2013, Mead 2014, NE, USA

b Chromosomal location

c From "GrainGene (http://wheat.pw.usda.gov/GG3)

${ }^{\mathrm{d}}$ Confirmed from this study

Table 6 Mean square from analysis of variance of putative markers for preharvest sprouting tolerance (Delta Value) in population 2 (NE98466/ NW99L7068)

\begin{tabular}{|c|c|c|c|c|c|c|}
\hline \multirow[t]{2}{*}{ Marker } & \multirow[t]{2}{*}{ Chromosome $^{\mathrm{b}}$} & \multicolumn{5}{|l|}{ Mean square $^{\mathrm{a}}$} \\
\hline & & Environment & Genotype & Entry (genotype) & Genotype $\times$ environment & Error \\
\hline Xbarc10 & $2 \mathrm{~B}^{\mathrm{c}}, 4 \mathrm{~B}^{\mathrm{c}}, 5 \mathrm{~A}^{\mathrm{c}}, 7 \mathrm{~B}^{\mathrm{c}}$ & $16,175^{* * *}$ & 223 & $1073 * * *$ & 336 & 368 \\
\hline Xbarc12 & $3 \mathrm{~A}^{\mathrm{d}}$ & $24,906 * * *$ & 5 & $1015 * * *$ & $830^{*}$ & 633 \\
\hline Xbarc54 & $3 A^{d}, 6 D^{c}$ & $23,996 * * *$ & $800^{*}$ & $986 * * *$ & 331 & 610 \\
\hline Xbarc55 & $1 \mathrm{~B}^{\mathrm{c}}, 2 \mathrm{~B}^{\mathrm{c}}, 5 \mathrm{~B}^{\mathrm{c}}$ & $21,934 * * *$ & 324 & $1015^{* * *}$ & 357 & 616 \\
\hline Xbarc59 & $2 \mathrm{D}^{\mathrm{c}}, 2 \mathrm{~B}^{\mathrm{c}}$ & $26,455^{* * *}$ & $7865 * * *$ & $979 * * *$ & $982 *$ & 624 \\
\hline Xbarc77 & $3 \mathrm{~A}^{\mathrm{d}}, 3 \mathrm{~B}^{\mathrm{c}}$ & $12,272 *$ & 198 & $969 * * *$ & 830 & 650 \\
\hline Xbarc105 & $3 \mathrm{~A}^{\mathrm{d}}, 7 \mathrm{~A}^{\mathrm{c}}, 7 \mathrm{D}^{\mathrm{c}}$ & $19,292 * * *$ & $2252 * *$ & $952 * * *$ & 504 & 603 \\
\hline Xbarc321 & $3 \mathrm{~A}^{\mathrm{c}}, 3 \mathrm{D}^{\mathrm{c}}$ & $24,462 * * *$ & 117 & $989 * * *$ & 884 & 621 \\
\hline Xcfd10 & $3 \mathrm{~A}^{\mathrm{d}}, 5 \mathrm{~A}^{\mathrm{c}}, 5 \mathrm{~B}^{\mathrm{c}}$ & $23,150 * * *$ & $4948 * * *$ & $957 * * *$ & 241 & 658 \\
\hline Xgwm132 & $3 A^{b}, 6 B^{c}, 6 D^{c}$ & $13,743 * * *$ & $3120 * * *$ & $800 * * *$ & 317 & 649 \\
\hline Xgwm261 & $2 \mathrm{D}^{\mathrm{c}}$ & $72,497 * * *$ & 1146 & $996 * * *$ & $1211^{*}$ & 583 \\
\hline Xwmc48 & $4 \mathrm{~A}^{\mathrm{c}}, 4 \mathrm{~B}^{\mathrm{c}}$ & $10,233 * * *$ & 381 & 849 & 426 & 614 \\
\hline Xwmc428 & $3 \mathrm{~A}^{\mathrm{d}}$ & $30,710 * * *$ & 669.9 & $849 * * *$ & 426 & 614 \\
\hline Xwmc552 & $3 \mathrm{~A}^{\mathrm{c}}, 3 \mathrm{D}^{\mathrm{c}}$ & $22,864 * * *$ & $1443^{*}$ & $1014 * * *$ & 72 & 649 \\
\hline Xwmc319 & $2 \mathrm{~B}^{\mathrm{c}}, 7 \mathrm{~A}^{\mathrm{c}}$ & $15,021 * *$ & $1926^{*}$ & $981 * * *$ & 504 & 582 \\
\hline
\end{tabular}

***, **, * Significant effects or difference observed at $P<0.05, P<0.10, P<0.25$ level

${ }^{\text {a }} F$ value was calculated using different error term in the Type 3 analysis of PROC MIXED Delta Value from 4 environments; Mead 2012, Mead 2013, Lincoln 2013, Mead 2014, NE, USA

b Chromosomal location

c From "GrainGene (http://wheat.pw.usda.gov/GG3)

d Confirmed from this study 
Table 7 Mean square from analysis of variance of putative markers for preharvest sprouting tolerance (Delta Value) in population 3 (Jagalene/ NW99L7068)

\begin{tabular}{|c|c|c|c|c|c|c|}
\hline \multirow[t]{2}{*}{ Marker } & \multirow[t]{2}{*}{ Chromosome $^{\mathrm{b}}$} & \multicolumn{5}{|l|}{ Mean square $^{a}$} \\
\hline & & Environment & Genotype & Entry (genotype) & Genotype $\times$ environment & Error \\
\hline Xbarc59 & $2 \mathrm{D}^{\mathrm{c}}, 5 \mathrm{~B}^{\mathrm{c}}$ & $38,908 * * *$ & $2767 * * *$ & $1089 * * *$ & 377 & 480 \\
\hline Xbarc105 & $3 \mathrm{~A}^{\mathrm{c}}, 7 \mathrm{~A}^{\mathrm{c}}, 7 \mathrm{D}^{\mathrm{c}}$ & $27,598 * * *$ & 524 & $1041 * * *$ & 437 & 486 \\
\hline Xcfd10 & $5 \mathrm{~A}^{\mathrm{c}}, 5 \mathrm{~B}^{\mathrm{c}}$ & $37,876^{* * *}$ & 24 & $1162 * * *$ & 129 & 490 \\
\hline Xgwm155 & $1 \mathrm{D}^{\mathrm{c}}, 3 \mathrm{~A}^{\mathrm{c}}$ & $40,534 * * *$ & $4729 * * *$ & $1035^{* * * *}$ & 342 & 507 \\
\hline Xgwm261 & $2 \mathrm{D}^{\mathrm{c}}$ & $41,694 * * *$ & $2142 * *$ & $1149 * * *$ & 790 & 492 \\
\hline Xgwm371 & $5 \mathrm{~B}^{\mathrm{c}}, 5 \mathrm{D}^{\mathrm{c}}$ & $40,700 * * *$ & $4268 * *$ & $1087 * * *$ & 454 & 492 \\
\hline Xgwm494 & $3 \mathrm{~A}^{\mathrm{c}}, 4 \mathrm{~A}^{\mathrm{c}}$ & $37,856 * * *$ & $2551^{*}$ & $1129 * * *$ & 564 & 504 \\
\hline Xgwmc48 & $4 \mathrm{~A}^{\mathrm{c}}, 4 \mathrm{~B}^{\mathrm{c}}$ & $39,930 * * *$ & 998 & $1111 * * *$ & 530 & 475 \\
\hline Xgwme428 & $3 \mathrm{~A}^{\mathrm{c}}$ & $39,079 * * *$ & $3593 * *$ & $1111 * * *$ & 529 & 495 \\
\hline Xwmc594 & $3 \mathrm{~A}^{\mathrm{c}}$ & $40,151 * * *$ & $1862 *$ & $1099 * * *$ & 513 & 482 \\
\hline Xwmc59 & $1 \mathrm{~A}^{\mathrm{c}}$ & $33,873 * * *$ & 1902 & $1121 * * *$ & $2424 * * *$ & 478 \\
\hline Xwms429 & $2 \mathrm{~B}^{\mathrm{c}}$ & $33,510 * * *$ & 7 & $931 * * *$ & $1317 * * *$ & 482 \\
\hline
\end{tabular}

***, **, * Significant effects or difference observed at $P<0.05, P<0.10, P<0.25$ level

${ }^{\text {a }} F$ value was calculated using different error term in the Type 3 analysis of PROC MIXED Delta Value from 4 environments; Mead 2012, Mead 2013, Lincoln 2013, Mead 2014, NE, USA

b Chromosomal location

c From "GrainGene (http://wheat.pw.usda.gov/GG3)

To further define the utility of marker-assisted selection for PHS tolerance, all potential possible combinations of unlinked loci, showing significant differences $(P<0.10)$ in single gene models (Table 8 ), were examined using two gene models (Tables 9 and 10). Putative alleles contributing to PHS tolerance, or lower Delta Value, were designated as "T", while "S", designated alleles contributed to susceptibility to PHS, or higher Delta Value.

Within Niobrara/NW99L7068 (Table 9), mean Delta Value scores of all TT classes (two putative PHS tolerant loci) were lower, and, hence, PHS tolerance was higher, than the SS classes (two putative susceptible loci). The same observations were evident in NE98466/NW99L7068 (Table 10) and Jagalene/NW99L7068 (Table 11). The TT class was always significantly lower in mean Delta Value than the SS class. In the two gene models, tolerance of PHS of the ST and TS classes (one putative tolerant locus and one putative susceptible locus) commonly showed intermediate results, indicating the action of additive genes.

\section{Discussion}

Previous studies have demonstrated that PHS tolerance is a quantitative trait (Fofana et al. 2009; Groos et al. 2002; Lawson et al. 1997; Liu et al. 2008). Herrmann (2007) and Jiang and Xiao (2005) explained that the genetic architecture associated with PHS in wheat is controlled by many genes with additive effects.
Liu et al. (2008), Liu and Bai (2010) found that Qphs. pseru-3AS, a QTL showed a major effect on tolerance to PHS. Liu et al. (2013) cloned a major locus (TaPHS1) and identified both positive (increasing tolerance) and negative (decreasing tolerance) alleles, and speculated that selection for or against these would improve PHS tolerance. In the present investigation, a wide range of PHS tolerance was observed, even though all lines were fixed for the positive TaPHSI allele. This study did demonstrate that PHS QTLs from previously studied wheat populations will be useful in developing Great Plains white wheats with enhanced PHS tolerance, and that the red wheat gene pool contains alleles, independent of seed coat color, that can be exploited in white wheat breeding. In the three breeding populations, loci contributing to $\mathrm{PHS}$ tolerance were located on chromosomes $2 \mathrm{~B}, 3 \mathrm{~A}, 3 \mathrm{~B}, 4 \mathrm{~B}, 5 \mathrm{~A}$ and 7B in Niobrara/NW99L7068, chromosomes 2B, 2D, 3A,5A, 5B, 6B, 6D, 7A and 7D in NE98466/NW99L7068 and chromosomes 1D, 2D, 3A, 5B and 5D in Jagalene/ NW99L7068. In the Niobrara/NW99L7068 population, two linkage groups were established: $\mathrm{Xgwm} 429$ and Xwmc319 on chromosome 2B; Xbar321, Xgwm132 and $\mathrm{Xwmc594}$ on chromosome 3A. One linkage group was identified in the NE98466/NW99L7068 population with Xbar77, Xbar54, Xbar12, Xbar105, Xgwm132, Xbar321, Xcfd10, Xwmc428, Xwmc552 and Xwmc96 located on chromosome 3A. A linkage group including Xcfd10 and Xwms429 was found in Jagalene/NW99L7068, however, the genomic location of these loci was unclear. To 
Table 8 Mean Delta Value for lines with respective parental alleles at loci with significant $(P<0.10)$ effects in three populations of hard white winter wheat

\begin{tabular}{|c|c|c|c|c|c|c|c|}
\hline \multirow[t]{2}{*}{ Population $^{\mathrm{a}}$} & \multirow[t]{2}{*}{ Loci } & \multirow[t]{2}{*}{ Chromosome $^{\mathrm{b}}$} & \multicolumn{3}{|c|}{ Parental allele } & \multirow[t]{2}{*}{ Parent } & \multirow[t]{2}{*}{ Putative effect } \\
\hline & & & No. lines ${ }^{\mathrm{e}}$ & $\operatorname{Mean}^{\mathrm{f}}$ & Std. err & & \\
\hline \multirow[t]{6}{*}{$\mathrm{I}=$ Niobrara/NW99L7068 } & \multirow[t]{2}{*}{ Xbarc10 } & \multirow[t]{2}{*}{$2 \mathrm{~B}^{\mathrm{c}}, 4 \mathrm{~B}^{\mathrm{c}}, 5 \mathrm{~A}^{\mathrm{c}}, 7 \mathrm{~B}^{\mathrm{c}}$} & 39 & 55.3 & 1.9 & Niobrara & S \\
\hline & & & 7 & 37.2 & 3.6 & NW99L7068 & $\mathrm{T}$ \\
\hline & \multirow[t]{2}{*}{ Xbarc77 } & \multirow[t]{2}{*}{$3 B^{c}$} & 29 & 46.8 & 2.2 & Niobrara & $\mathrm{T}$ \\
\hline & & & 109 & 52.5 & 1.2 & NW99L7068 & $\mathrm{S}$ \\
\hline & \multirow[t]{2}{*}{ Xwmc594 } & \multirow[t]{2}{*}{$3 \mathrm{~A}^{\mathrm{c}, \mathrm{d}}$} & 36 & 45.5 & 1.7 & Niobrara & $\mathrm{T}$ \\
\hline & & & 99 & 54.1 & 1.3 & NW99L7068 & $\mathrm{S}$ \\
\hline \multirow[t]{8}{*}{$\mathrm{II}=\mathrm{NE98466/NW99L7068}$} & \multirow[t]{2}{*}{ Xbarc59 } & \multirow[t]{2}{*}{$2 \mathrm{D}^{\mathrm{c}}, 2 \mathrm{~B}^{\mathrm{c}}$} & 78 & 57.4 & 1.5 & NE98466 & $\mathrm{T}$ \\
\hline & & & 72 & 64.4 & 1.8 & NW99L7068 & $\mathrm{S}$ \\
\hline & \multirow[t]{2}{*}{ Xcfd10 } & \multirow[t]{2}{*}{$3 \mathrm{~A}^{\mathrm{c}}, 5 \mathrm{~A}^{\mathrm{c}}, 5 \mathrm{~B}^{\mathrm{c}}$} & 79 & 64.1 & 1.6 & NE98466 & $\mathrm{S}$ \\
\hline & & & 60 & 60.0 & 1.9 & NW99L7068 & $\mathrm{T}$ \\
\hline & \multirow[t]{2}{*}{ Xgwm132 } & \multirow[t]{2}{*}{$3 \mathrm{~A}^{\mathrm{d}}, 6 \mathrm{~B}^{\mathrm{d}}, 6 \mathrm{D}^{\mathrm{d}}$} & 30 & 52.5 & 2.4 & NE98466 & $\mathrm{T}$ \\
\hline & & & 81 & 63.0 & 1.6 & NW99L7068 & $\mathrm{S}$ \\
\hline & \multirow[t]{2}{*}{ Xbarc105 } & \multirow[t]{2}{*}{$3 \mathrm{~A}^{\mathrm{d}}, 7 \mathrm{~A}^{\mathrm{c}}, 7 \mathrm{D}^{\mathrm{c}}$} & 86 & 63.4 & 1.6 & NE98466 & $\mathrm{S}$ \\
\hline & & & 37 & 54.9 & 2.1 & NW99L7068 & $\mathrm{T}$ \\
\hline \multirow[t]{10}{*}{ III = Jagalene/NW99L7068 } & \multirow[t]{2}{*}{ Xbarc59 } & \multirow[t]{2}{*}{$2 \mathrm{D}^{\mathrm{c}}, 5 \mathrm{~B}^{\mathrm{c}}$} & 67 & 62.7 & 1.6 & Jagalene & $\mathrm{T}$ \\
\hline & & & 73 & 66.9 & 1.8 & NW99L7068 & $\mathrm{S}$ \\
\hline & \multirow[t]{2}{*}{ Xgwm155 } & \multirow[t]{2}{*}{$1 \mathrm{D}^{\mathrm{e}}, 3 \mathrm{~A}^{\mathrm{d}}$} & 65 & 68.5 & 2.0 & Jagalene & $\mathrm{S}$ \\
\hline & & & 75 & 62.8 & 1.5 & NW99L7068 & $\mathrm{T}$ \\
\hline & \multirow[t]{2}{*}{ Xgwm261 } & \multirow[t]{2}{*}{$2 \mathrm{D}^{\mathrm{c}}$} & 83 & 67.1 & 1.7 & Jagalene & $\mathrm{S}$ \\
\hline & & & 60 & 63.4 & 1.8 & NW99L7068 & $\mathrm{T}$ \\
\hline & \multirow[t]{2}{*}{ Xgwm371 } & \multirow[t]{2}{*}{$5 \mathrm{~B}^{\mathrm{c}}, 5 \mathrm{D}^{\mathrm{c}}$} & 61 & 62.6 & 1.9 & Jagalene & $\mathrm{T}$ \\
\hline & & & 78 & 67.8 & 1.7 & NW99L7068 & $\mathrm{S}$ \\
\hline & \multirow[t]{2}{*}{ Xwmc428 } & $4 \mathrm{~A}^{\mathrm{a}}, 4 \mathrm{~B}^{\mathrm{a}}$ & 70 & 67.7 & 1.8 & Jagalene & $\mathrm{S}$ \\
\hline & & & 71 & 62.8 & 1.7 & NW99L7068 & $\mathrm{T}$ \\
\hline
\end{tabular}

$T$ allele associated with greater tolerance to pre-harvest sprouting, $S$ allele associated with greater susceptibility

a Delta Value from 4 environments; Mead 2012, Mead 2013, Lincoln 2013, Mead 2014, NE, USA

b Chromosomal location

c From "GrainGene (http://wheat.pw.usda.gov/GG3)

d Confirmed from this study

e Only homogeneous, homozygous lines included

${ }^{\mathrm{f}}$ Means are presented only for those markers with significant $(P<0.10)$ differences indicated by ANOVA

Table 9 Mean sprouting tolerance of genotypes identified by two independent loci (Niobrara/NW99L7068)

\begin{tabular}{|c|c|c|c|c|c|c|c|c|c|c|}
\hline \multicolumn{4}{|l|}{ Locus 1} & \multicolumn{4}{|l|}{ Locus 2} & \multicolumn{3}{|c|}{ Delta Value } \\
\hline Loci & Chromosome & Genotype $^{b}$ & Effect & Loci & Chromosome & Genotype & Effect & No. lines & (Tolerance) mean & Std. err \\
\hline \multirow[t]{4}{*}{ Xbarc $77^{\mathrm{a}}$} & $3 B$ & Niobrara & $\mathrm{T}$ & Xwmc594 & $3 \mathrm{~A}$ & Niobrara & $\mathrm{T}$ & 14 & $47.5 \mathrm{ab}$ & 2.9 \\
\hline & & Niobrara & $\mathrm{T}$ & & & NW99L7068 & S & 11 & $49.2 \mathrm{ab}$ & 4.0 \\
\hline & & NW99L7068 & $\mathrm{S}$ & & & NW99L7068 & $S$ & 83 & $55.2 \mathrm{~b}$ & 1.4 \\
\hline & & NW99L7068 & $\mathrm{S}$ & & & Niobrara & $\mathrm{T}$ & 22 & $44.3 \mathrm{a}$ & 2.2 \\
\hline
\end{tabular}

Means followed by the same letter were not significantly different, $P<0.10$

${ }^{a}$ Putative phenotyic effect from single-locus analysis (see Table 6)

${ }^{\mathrm{b}}$ Genotye $=$ parental origin of respective alleles 
Table 10 Mean sprouting tolerance of genotypes identified by two independent loci (NE98466/NW99L7068)

\begin{tabular}{|c|c|c|c|c|c|c|c|c|c|c|}
\hline \multicolumn{4}{|l|}{ Locus 1} & \multicolumn{4}{|l|}{ Locus 2} & \multicolumn{3}{|c|}{ Delta Value } \\
\hline Loci & Chromosome & Genotype $^{a}$ & Effect & Loci & Chromosome & Genotype & Effect & No. lines & (Tolerance) Mean & Std. err \\
\hline \multirow[t]{4}{*}{ Xbarc59 } & \multirow[t]{4}{*}{$2 \mathrm{~B}, 2 \mathrm{D}$} & NE98466 & $\mathrm{T}$ & \multirow[t]{4}{*}{ Xbarc105 } & \multirow[t]{4}{*}{ 3A, 7A, 7D } & NE98466 & $\mathrm{S}$ & 22 & $60.1 \mathrm{ab}$ & 2.8 \\
\hline & & NE98466 & $\mathrm{T}$ & & & NW99L7068 & $\mathrm{T}$ & 50 & $56.3 \mathrm{a}$ & 1.9 \\
\hline & & NW99L7068 & $\mathrm{S}$ & & & NW99L7068 & $\mathrm{T}$ & 51 & $63.8 \mathrm{ab}$ & 2.0 \\
\hline & & NW99L7068 & $\mathrm{S}$ & & & NE98466 & $\mathrm{S}$ & 12 & $66.4 \mathrm{~b}$ & 4.9 \\
\hline \multirow[t]{4}{*}{ Xbarc59 } & \multirow[t]{4}{*}{$2 \mathrm{~B}, 2 \mathrm{D}$} & NE98466 & $\mathrm{T}$ & \multirow[t]{4}{*}{ Xcfd10 } & \multirow[t]{4}{*}{$5 \mathrm{~A}, 5 \mathrm{~B}$} & NE98466 & $\mathrm{S}$ & 35 & $63.6 b$ & 2.4 \\
\hline & & NE98466 & $\mathrm{T}$ & & & NW99L7068 & $\mathrm{T}$ & 33 & $51.1 \mathrm{a}$ & 2.3 \\
\hline & & NW99L7068 & $\mathrm{S}$ & & & NW99L7068 & $\mathrm{T}$ & 24 & $65.6 \mathrm{~b}$ & 3.2 \\
\hline & & NW99L7068 & $\mathrm{S}$ & & & NE98466 & $\mathrm{S}$ & 40 & $65.1 \mathrm{~b}$ & 2.4 \\
\hline \multirow[t]{4}{*}{ Xbarc59 } & \multirow[t]{4}{*}{$2 \mathrm{~B}, 2 \mathrm{D}$} & NE98466 & $\mathrm{T}$ & \multirow[t]{4}{*}{ Xgwm132 } & \multirow[t]{4}{*}{$6 \mathrm{~B}, 6 \mathrm{D}$} & NE98466 & $\mathrm{T}$ & 21 & $51.4 \mathrm{a}$ & 3.1 \\
\hline & & NE98466 & $\mathrm{T}$ & & & NW99L7068 & $\mathrm{S}$ & 33 & $58.4 \mathrm{a}$ & 2.3 \\
\hline & & NW99L7068 & $\mathrm{S}$ & & & NW99L7068 & $\mathrm{S}$ & 45 & $66.2 b$ & 2.3 \\
\hline & & NW99L7068 & $\mathrm{S}$ & & & NE98466 & $\mathrm{T}$ & 10 & $56.8 \mathrm{ab}$ & 4.1 \\
\hline \multirow[t]{4}{*}{ Xbarc105 } & \multirow[t]{4}{*}{ 3A, 7A, 7D } & NE98466 & $\mathrm{S}$ & \multirow[t]{4}{*}{ Xcfd10 } & \multirow[t]{4}{*}{$5 \mathrm{~A}, 5 \mathrm{~B}$} & NE98466 & $\mathrm{S}$ & 12 & $70.0 \mathrm{~b}$ & 4.4 \\
\hline & & NE98466 & $\mathrm{S}$ & & & NW99L7068 & $\mathrm{T}$ & 60 & $62.4 \mathrm{ab}$ & 1.8 \\
\hline & & NW99L7068 & $\mathrm{T}$ & & & NW99L7068 & $\mathrm{T}$ & 36 & $56.6 \mathrm{a}$ & 2.5 \\
\hline & & NW99L7068 & $\mathrm{T}$ & & & NE98466 & $\mathrm{S}$ & 17 & $58.8 \mathrm{ab}$ & 3.2 \\
\hline \multirow[t]{4}{*}{ Xbarc105 } & \multirow[t]{4}{*}{ 3A, 7A, 7D } & NE98466 & $\mathrm{S}$ & \multirow[t]{4}{*}{ Xgwm132 } & \multirow[t]{4}{*}{$6 \mathrm{~B}, 6 \mathrm{D}$} & NE98466 & $\mathrm{T}$ & 9 & $56.2 \mathrm{ab}$ & 4.5 \\
\hline & & NE98466 & $\mathrm{S}$ & & & NW99L7068 & $\mathrm{S}$ & 9 & $61.9 \mathrm{ab}$ & 4.2 \\
\hline & & NW99L7068 & $\mathrm{T}$ & & & NW99L7068 & $\mathrm{S}$ & 64 & $62.7 b$ & 1.8 \\
\hline & & NW99L7068 & $\mathrm{T}$ & & & NE98466 & $\mathrm{T}$ & 20 & $52.9 \mathrm{a}$ & 3.1 \\
\hline \multirow[t]{4}{*}{ Xcfd10 } & \multirow[t]{4}{*}{$5 \mathrm{~A}, 5 \mathrm{~B}$} & NE98466 & $\mathrm{S}$ & \multirow[t]{4}{*}{ Xgwm132 } & \multirow[t]{4}{*}{$6 \mathrm{~B}, 6 \mathrm{D}$} & NE98466 & $\mathrm{T}$ & 7 & $55.1 \mathrm{ab}$ & 5.3 \\
\hline & & NE98466 & $\mathrm{S}$ & & & NW99L7068 & $\mathrm{S}$ & 50 & $65.3 b$ & 2.1 \\
\hline & & NW99L7068 & $\mathrm{T}$ & & & NW99L7068 & $\mathrm{S}$ & 24 & $59.2 \mathrm{ab}$ & 2.9 \\
\hline & & NW99L7068 & $\mathrm{T}$ & & & NE98466 & $\mathrm{T}$ & 18 & $50.0 \mathrm{a}$ & 3.1 \\
\hline
\end{tabular}

Means followed by the same letter were not significantly different, $P<0.10$

a Genotype $=$ parental origin of respective alleles

develop lines with greater tolerance to PHS, these genes can be pyramided with each other, as per Graybosch et al. (2013).

The contribution of parental alleles to PHS tolerance of progeny genotypes was not always predicted by the parental phenotypes. For example, NW98466 contributed both $\mathrm{T}$ and $\mathrm{S}$ alleles (Tables 9, 10). Similar observations were made for parental genotypes Niobrara, Jagalene and NW99L7068. NW99L7068, the susceptible white wheat parent, still contributed some positive alleles. The pedigree of NW99L7068 includes RioBlanco, a PHS tolerant cultivar (Morris and Paulsen 1992), and perhaps it is able to contribute positive alleles once they are free of other negative alleles within the genome. Jagalene, a PHS tolerant wheat, still produced both susceptible and tolerant progenies. While significant effects were observed via pyramiding of $\mathrm{T}$ alleles, it was clear the effects were slight. All observations still confirm the quantitative and additive nature of the inheritance of PHS tolerance, and suggest pyramiding of multiple $\mathrm{T}$ alleles should be conducted to improve the chances of identifying PHS tolerant cultivars.

The polymorphic markers did not consistently identify loci across populations due to the difference of genetic background and different genes involved in each population. Tolerance to PHS is also strongly affected by environmental factors (Zanetti et al. 2000) and genetic, gene interactions and $\mathrm{G} \times \mathrm{E}$ interaction (Flintham 2000; Mares et al. 2005), though significant interactions between marker loci and environment rarely were observed in the present study. Additional loci in wheat cultivars must contribute to the interactions observed with environment. ( $\mathrm{Gu}$ et al. 2004; 2006) noted that tolerance to PHS is controlled by many QTLs with various effects. Hence, these results can be explained by additive gene effects. No doubt, additional markers need to be identified to explain the observed variation both within and across these and other breeding populations. In all populations, transgressive segregation 
Table 11 Mean sprouting tolerance of genotypes identified by two independent loci (Jagalene/NW99L7068)

\begin{tabular}{|c|c|c|c|c|c|c|c|c|c|c|}
\hline \multicolumn{4}{|l|}{ Locus 1} & \multicolumn{4}{|l|}{ Locus 2} & \multicolumn{3}{|c|}{ Delta Value } \\
\hline Loci & Chromosome & Genotype $^{a}$ & Effect & Loci & Chromosome & Genotype & Effect & No. lines & Mean & Std. err \\
\hline \multirow[t]{4}{*}{ Xbarc59 } & \multirow[t]{4}{*}{$2 \mathrm{~B}, 2 \mathrm{D}$} & Jagalene & $\mathrm{T}$ & \multirow[t]{4}{*}{ Xgwm155 } & \multirow[t]{4}{*}{$1 \mathrm{D}, 3 \mathrm{~A}$} & Jagalene & $\mathrm{S}$ & 26 & $64.1 \mathrm{ab}$ & 2.2 \\
\hline & & Jagalene & $\mathrm{T}$ & & & NW99L7068 & $\mathrm{T}$ & 37 & $62.0 \mathrm{~b}$ & 2.2 \\
\hline & & NW99L7068 & $\mathrm{S}$ & & & NW99L7068 & $\mathrm{T}$ & 36 & $62.5 b$ & 2.2 \\
\hline & & NW99L7068 & $\mathrm{S}$ & & & Jagalene & $\mathrm{S}$ & 33 & $70.6 \mathrm{a}$ & 2.9 \\
\hline \multirow[t]{4}{*}{ Xbarc59 } & \multirow[t]{4}{*}{$2 \mathrm{~B}, 2 \mathrm{D}$} & Jagalene & $\mathrm{T}$ & \multirow[t]{4}{*}{ Xgwm261 } & \multirow[t]{4}{*}{$2 \mathrm{D}$} & Jagalene & $\mathrm{S}$ & 38 & $63.4 \mathrm{a}$ & 2.2 \\
\hline & & Jagalene & $\mathrm{T}$ & & & NW99L7068 & $\mathrm{T}$ & 25 & $61.8 \mathrm{ab}$ & 2.6 \\
\hline & & NW99L7068 & $\mathrm{S}$ & & & NW99L7068 & $\mathrm{T}$ & 29 & $62.5 b$ & 2.6 \\
\hline & & NW99L7068 & $\mathrm{S}$ & & & Jagalene & $\mathrm{S}$ & 42 & $69.8 \mathrm{a}$ & 2.6 \\
\hline \multirow[t]{4}{*}{ Xbarc59 } & \multirow[t]{4}{*}{$2 \mathrm{~B}, 2 \mathrm{D}$} & Jagalene & $\mathrm{T}$ & \multirow[t]{4}{*}{ Xgwm371 } & \multirow[t]{4}{*}{$5 B$} & Jagalene & $\mathrm{T}$ & 24 & $60.0 \mathrm{~b}$ & 2.9 \\
\hline & & Jagalene & $\mathrm{T}$ & & & NW99L7068 & $\mathrm{S}$ & 39 & $65.5 a$ & 2.7 \\
\hline & & NW99L7068 & $\mathrm{S}$ & & & NW99L7068 & $\mathrm{S}$ & 34 & $69.8 \mathrm{a}$ & 2.7 \\
\hline & & NW99L7068 & $\mathrm{S}$ & & & Jagalene & $\mathrm{T}$ & 36 & $64.1 \mathrm{ab}$ & 2.6 \\
\hline \multirow[t]{4}{*}{ Xbarc59 } & \multirow[t]{4}{*}{$2 \mathrm{~B}, 2 \mathrm{D}$} & Jagalene & $\mathrm{T}$ & \multirow[t]{4}{*}{ Xwmc594 } & \multirow[t]{4}{*}{$3 \mathrm{~A}$} & Jagalene & $\mathrm{S}$ & 30 & $63.3 a$ & 2.3 \\
\hline & & Jagalene & $\mathrm{T}$ & & & NW99L7068 & $\mathrm{T}$ & 32 & $61.5 b$ & 2.6 \\
\hline & & NW99L7068 & $\mathrm{S}$ & & & NW99L7068 & $\mathrm{T}$ & 33 & $62.6 a$ & 2.5 \\
\hline & & NW99L7068 & $\mathrm{S}$ & & & Jagalene & $\mathrm{S}$ & 39 & $70.2 \mathrm{a}$ & 2.6 \\
\hline \multirow[t]{4}{*}{ Xgwm155 } & \multirow[t]{4}{*}{$1 \mathrm{D}, 3 \mathrm{~A}$} & Jagalene & $\mathrm{S}$ & \multirow[t]{4}{*}{ Xgwm261 } & \multirow[t]{4}{*}{$2 \mathrm{D}$} & Jagalene & $\mathrm{S}$ & 45 & $68.5 \mathrm{a}$ & 2.4 \\
\hline & & Jagalene & $\mathrm{S}$ & & & NW99L7068 & $\mathrm{T}$ & 16 & $68.1 \mathrm{a}$ & 4.1 \\
\hline & & NW99L7068 & $\mathrm{T}$ & & & NW99L7068 & $\mathrm{T}$ & 41 & $61.3 b$ & 2.0 \\
\hline & & NW99L7068 & $\mathrm{T}$ & & & Jagalene & $\mathrm{S}$ & 34 & $64.4 \mathrm{ab}$ & 2.3 \\
\hline Xgwm155 & $1 \mathrm{D}, 3 \mathrm{~A}$ & Jagalene & $\mathrm{S}$ & Xgwm371 & $5 \mathrm{~B}$ & Jagalene & $\mathrm{T}$ & 27 & $62.9 b$ & 3.1 \\
\hline & & Jagalene & $\mathrm{S}$ & & & NW99L7068 & $\mathrm{S}$ & 32 & $73.3 \mathrm{a}$ & 2.8 \\
\hline & & NW99L7068 & $\mathrm{T}$ & & & NW99L7068 & $\mathrm{S}$ & 44 & $62.8 b$ & 2.0 \\
\hline & & NW99L7068 & $\mathrm{T}$ & & & Jagalene & $\mathrm{T}$ & 28 & $62.3 b$ & 2.6 \\
\hline Xgwm155 & $1 \mathrm{D}, 3 \mathrm{~A}$ & Jagalene & $\mathrm{S}$ & Xwmc594 & $3 \mathrm{~A}$ & Jagalene & $\mathrm{S}$ & 32 & $71.9 \mathrm{a}$ & 2.9 \\
\hline & & Jagalene & $\mathrm{S}$ & & & NW99L7068 & $\mathrm{T}$ & 27 & $63.4 b$ & 3.0 \\
\hline & & NW99L7068 & $\mathrm{T}$ & & & NW99L7068 & $\mathrm{T}$ & 41 & $62.3 b$ & 2.1 \\
\hline & & NW99L7068 & $\mathrm{T}$ & & & Jagalene & $\mathrm{S}$ & 43 & $62.6 b$ & 2.3 \\
\hline Xgwm261 & $2 \mathrm{D}$ & Jagalene & $\mathrm{S}$ & Xgwm371 & $5 B$ & Jagalene & $\mathrm{T}$ & 36 & $63.1 \mathrm{~b}$ & 2.6 \\
\hline & & Jagalene & $\mathrm{S}$ & & & NW99L7068 & $\mathrm{S}$ & 43 & $71.1 \mathrm{a}$ & 2.3 \\
\hline & & NW99L7068 & $\mathrm{T}$ & & & NW99L7068 & $\mathrm{S}$ & 32 & $63.2 b$ & 2.3 \\
\hline & & NW99L7068 & $\mathrm{T}$ & & & Jagalene & $\mathrm{T}$ & 36 & $61.4 b$ & 2.3 \\
\hline Xgwm261 & $2 \mathrm{D}$ & Jagalene & $\mathrm{S}$ & Xwmc428 & $3 \mathrm{~A}$ & Jagalene & $\mathrm{S}$ & 46 & $71.0 \mathrm{a}$ & 2.4 \\
\hline & & Jagalene & $\mathrm{S}$ & & & NW99L7068 & $\mathrm{T}$ & 32 & $61.2 b$ & 2.6 \\
\hline & & NW99L7068 & $\mathrm{T}$ & & & NW99L7068 & $\mathrm{T}$ & 36 & $64 \mathrm{ab}$ & 2.3 \\
\hline & & NW99L7068 & $\mathrm{T}$ & & & Jagalene & $\mathrm{S}$ & 21 & $60.0 \mathrm{~b}$ & 2.8 \\
\hline Xgwm371 & $5 \mathrm{~B}$ & Jagalene & $\mathrm{T}$ & Xwmc428 & $3 \mathrm{~A}$ & Jagalene & $\mathrm{S}$ & 29 & 66.0ab & 2.9 \\
\hline & & Jagalene & $\mathrm{T}$ & & & NW99L7068 & $\mathrm{T}$ & 30 & $58.5 \mathrm{bc}$ & 2.6 \\
\hline & & NW99L7068 & $\mathrm{S}$ & & & NW99L7068 & $\mathrm{T}$ & 37 & $65.9 \mathrm{ab}$ & 2.4 \\
\hline & & NW99L7068 & $\mathrm{S}$ & & & Jagalene & $\mathrm{S}$ & 36 & $70.0 \mathrm{a}$ & 2.5 \\
\hline
\end{tabular}

Means followed by the same letter were not significantly different, $P<0.10$

${ }^{a}$ Genotype $=$ parental origin of respective alleles

for PHS tolerance was observed. Similar to the results reported here for hexaploid wheat, Knox et al. (2012) noted that transgressive segregation occurred for greater
PHS tolerance in a durum wheat population from a cross between moderately susceptible and intermediate PHS tolerant parents. 


\section{Conclusions}

In three breeding populations in which all lines were fixed for the major PHS tolerance allele of TaPHS1, a wide range of variation was observed, indicating that there are many minor genes involved with PHS tolerance in all three populations. Chromosome 3A, upon which TaPHSI resides, still was demonstrated to house additional loci influencing the trait. This chromosome should be subjected to intensive investigation to further define its critical role in PHS tolerance.

QTLs from previously studied wheat populations were found to influence PHS in Great Plains white wheats. These alleles were derived from hard red wheats, and are independent of seed coat color. Due to the different genes and differences of genetic backgrounds, markers indicating positive alleles will not consistently identify positive phenotypes across populations. In addition, crossing PHS tolerant parental genotypes may not guarantee good tolerance to PHS in their progenies, due to negative transgressive segregation. Crossing susceptible PHS parental genotypes could contribute some PHS tolerance, a result of positive transgressive segregation. In addition, environmental effects modulate the expression of PHS tolerance, and might mask genotypic effects. However, genotype $\times$ environment effects were minimal, confirming the potential use of marker-assisted selection for PHS tolerance improvement.

Author contributions statement Juthamas Fakthongphan conducted field and laboratory experiments, analyzed data and drafted manuscript. R.A. Graybosch and P.S. Baenziger developed genetic materials, designed the experiments, analyzed data and drafted manuscript. Paul St. Amand and Guihua Bai conducted DNA marker analyses and assisted with manuscript preparation.

\section{Compliance with ethical standards}

Conflict of interest The authors declare no conflict of interest.

\section{References}

Baenziger PS, Moreno-Sevilla B, Peterson CJ, Schmidt JW, Shelton DR, Baltensperger DD, Graybosch RA (1996) Registration of 'Niobrara' wheat. Crop Sci 36(3):803

Bewley JD, Black M (1982) Physiological and biochemistry of seeds in relation to germination, vol 2. Springer, Berlin, pp 61-81

Clarke FR, Clarke JM, DePauw RM, Fernandez MR, Fox S, Gilbert J, Humphreys G, Knox RE, McCaig TN, Procunier D, Sissons M, Somers D (2005) Strategic approach to mitigating weather induced defects of wheat quality. Euphytica 143:285-290

DePauw RM, Knox RE, Singh AK, Fox SL, Humphreys DG, Hucl P (2012) Developing standardized methods for breeding pre-harvest sprouting resistant wheat, challenges and successes in Canadian wheat. Euphytica 188:7-14

Doyle JJ, Doyle JL (1987) A rapid DNA isolation procedure for small quantities of fresh leaf tissue. Phytochem Bull 19:11-15

Fakthongphan J (2015) Potential of red wheats to donate genes influencing preharvest sprouting of white wheats, independent of grain color. PhD Dissertation, University of Nebraska-Lincoln. Nebraska, USA

Flintham JE (2000) Different genetic components control coatimposed and embryo imposed dormancy in wheat. Seed Sci Res $10: 43-50$

Flintham JE, Adlam R, Gale MD (1999) Seed coat and embryo dormancy in wheat. In: Weipert D (ed) Eighth international symposium on pre-harvest sprouting in cereals. Association of Cereal Research, Detmold, pp 67-76

Fofana B, Humphreys DG, Rasul G, Cloutier S, Brûlé-Babel A, Woods S, Lukow OM, Somers DJ (2009) Mapping quantitative trait loci controlling pre-harvest sprouting resistance in a red $\times$ white seeded spring wheat cross. Euphytica 165:509-521

Graybosch RA, St Amand P, Bai G (2013) Evaluation of genetic markers for prediction of preharvest sprouting tolerance in hard white winter wheats. Plant Breed 132:359-366

Groos C, Gay G, Perretant MR, Gervais L, Bernard M, Dedryver F, Charmet G (2002) Study of the relationship between pre-harvest sprouting and grain color by quantitative trait loci analysis in a white-red grain bread wheat cross. Theor Appl Genet 104:39-47

Gu XY, Kianian SF, Foley ME (2004) Multiple loci and epitases control genetic variation for seed dormancy in weedy rice (Oryza sativa). Genetics 166:1503-1516

Gu X-Y, Kianian SF, Foley ME (2006) Isolation of three dormancy QTLs as Mendelian factors in rice. Heredity 96:93-99

Guyomarc'h H, Sourdille P, Edwards KJ, Bernard M (2002) Studies of the transferability of microsatellites derived from Triticum tauschii to hexaploid wheat and to diploid related species using amplification, hybridization and sequence comparisons. Theor Appl Genet 105:736-744

Herrmann M (2007) A diallel analysis of various traits in winter triticale. Plant Breed 126:19-23

Ibrahim A, Langham M, Rickertsen J, Kalsbeck S, Little R, Haley S, Baenziger P, Chung OK, Seabourn BW, Jin Y, Mcvey DV, Bai G (2008) Registration of 'Darrell' wheat. J Plant Reg 2:115-121

Jiang G-L, Xiao S (2005) Factorial cross analysis of pre-harvest sprouting resistance in white wheat. Field Crop Res 91:63-69

Kato K, Nakamura W, Tabiki T, Miura H, Sawada S (2001) Detection of loci controlling seed dormancy on group 4 chromosomes of wheat and comparative mapping with rice and barley genomes. Theor Appl Genet 102:980-985

Knox RE, Clarke FR, Clarke JM, Fox SL, DePauw RM, Singh AK (2012) Enhancing the identification of genetic loci and transgressive segregants for preharvest sprouting resistance in a durum wheat population. Euphytica 186:193-206

Kottearachchi NS, Uchino N, Kato K (2006) Increased grain dormancy in white-grained wheat by introgression of preharvest sprouting tolerance QTLs. Euphytica 152:421-428

Kulwal PL, Singh R, Balyan HS, Khurana P, Khurana JP, Tyagi AK, Balyan HS, Gupta PK (2005) Mapping of a major QTl for preharvest sprouting tolerance on chromosome $3 \mathrm{~A}$ in bread wheat. Theor Appl Genet 111:1357-1364

Lawson RW, Godwin ID, Cooper M, Brennan PS (1997) Genetic analysis of preharvest sprouting tolerance in three wheat crosses. Aust J Agric Res 48:215-221

Li C, Ni P, Francki M, Hunter A, Zhang Y, Schibeci D, Li H, Tarr A, Wang J, Cakir M, Yu J, Bellgard M, Lance R, Appels R (2004) Genes controlling seed dormancy and pre-harvest sprouting in a rice-wheat-barley comparison. Funct Integr Genom 4:84-93 
Liu S, Bai G (2010) Dissection and fine mapping of a major QTL for preharvest sprouting resistance in white wheat Rio Blanco. Theor Appl Genet 121:1395-1404

Liu S, Cai S, Graybosch R, Chen C, Bai G (2008) Quantitative trait loci for resistance to pre-harvest sprouting in US hard white winter wheat Rio Blanco. Theor Appl Genet 117:691-699

Liu S, Sehgal SK, Li J, Lin M, Trick HN, Yu J, Gill BS, Bai G (2013) Cloning and characterization of a critical regulator for preharvest sprouting in wheat. Genetics 195:263-273

Lorieux M (2012) MapDisto: fast and efficient computation of genetic linkage maps. Mol Breed 30:1231-1235

Mares D, Mrva K, Cheong J, Williams K, Watson B, Storlie E, Sutherland M, Zou Y (2005) A QTL located on chromosome 4A associated with Dormancy in white and red-grained wheats of diverse origin. Theor Appl Genet 111:1357-1364

McKibbin RS, Wilkinson MD, Bailey PC, Flintham JE, Andrew LM, Lazzeri PA, Gale D, Lenton JR, Holdsworth MJ (2002) Transcripts of $V p-1$ homeologues are misspliced in modern wheat and ancestral species. Proc Natl Acad Sci USA 99(15):10203-10208

Morris CF, Paulsen GM (1989) Registration of five preharvest sprouting-resistant hard white winter wheat germplasm. Crop Sci 29:246-247

Morris CF, Paulsen GL (1992) Review: research on pre-harvest sprouting resistance in hard red and white winter wheats at Kansas State University. In: Walker-Simmons MD, and Reid JJ (eds) Pre-Harvest Sprouting in Cereals. Am. Assoc. of Cereal Chemists. St. Paul. MN, pp 113-120

Nakamura S, Abe F, Kawahigashi H, Nakazono K, Tagiri A, Matsumoto T, Utsugi S, Ogawa T, Handa $\mathrm{H}$, Ishida $\mathrm{H}$, Mori $\mathrm{M}$, Kawaura K, Ogihara Y, Miura H (2011) A wheat homolog of MOTHER OF FT AND TFL1 acts in the regulation of germination. Plant Cell 23:3215-3229

Pearson T, Brabec D, Haley S (2008) Color image based sorter for separating red and white wheat. Sens Instrum Food Qual 2:280-288
Röder MS, Korzun V, Wendehake K, Plaschke J, Tixier MH, Leroy P, Ganal MW (1998) A microsatellite map of wheat. Genetics 149:2007-2023

Ross AS, Bettge AD (2009) Passing the test of wheat end-use quality. In: Carver BF (ed) Wheat Science and Trade. Wildey-Blackwell, Oxford, pp 445-493

Roy JK, Prasad M, Varshney RK, Balyan HS, Blake TK, Dhaliwal HS, Singh H, Edwards KJ, Gupta PK (1999) Identification of a microsatellite on chromosomes 6B and a STS on 7D of bread wheat showing an association with preharvest sprouting tolerance. Theor Appl Genet 99:336-340

Sing R, Matus-Cádiz M, Båga M, Hucl P, Chibbar RN (2010) Identification of genomic regions associated with seed dormancy in white-grained wheat. Euphytica 174:391-408

Sing R, Hucl P, Båga M, Chibbar RN (2012) Validation of molecular markers for pre-harvest sprouting resistance in bread wheat. Cereal Res Commun 40(2):194-203

Singh AK, Knox RE, Clarke JM, Clarke FR, Singh A, DePauw RM, Cuthbert RD (2014) Genetics of pre-harvest sprouting resistance in a cross of Canadian adapted durum wheat genotypes. Mol Breed 33:919-929

Somers DJ, Isaac P, Edwards K (2004) A high-density wheat microsatellite consensus map for bread wheat (Triticum aestivum L.). Theor Appl Genet 109:1105-1114

Song QJ, Shi JR, Singh S, Fickus EW, Costa JM, Lewis J, Gill BS, Ward R, Cregan PB (2005) Development and mapping of microsatellite (SSR) markers in wheat. Theor Appl Genet 110:550-560

Wu J, Carver B (1999) Sprout damage and preharvest sprout resistance in hard white winter wheat. Crop Sci 39:441-447

Zanetti S, Winzeler M, Keller M, Keller B, Messmer M (2000) Genetic analysis of pre-harvest sprouting resistance in a wheat $\times$ spelt cross. Crop Sci 40:1406-1417 


\section{Supplementary material}

Supplementary Table S1 Primers used in DNA marker analysis

\begin{tabular}{|c|c|c|c|c|}
\hline Primer & Sequence & DNA SequenceTailed & $\begin{array}{c}\text { Locus/ } \\
\text { Putative } \\
\text { Chromosomes } \\
\text { as per Grain } \\
\text { genes } \\
\end{array}$ & $\begin{array}{c}\text { Putative } \\
\text { chromosome } \\
\text { (this study) }\end{array}$ \\
\hline BARC10F18 & $\begin{array}{l}\text { GCGTGCCACTGTAACCTTTAGAA } \\
\text { GA }\end{array}$ & $\begin{array}{l}\text { ACGACGTTGTAAAACGACGCGTGC } \\
\text { CACTGTAACCTTTAGAAGA }\end{array}$ & $\begin{array}{l}\text { Xbarc10, 2B, } \\
4 \mathrm{~B}, 5 \mathrm{~A}, 7 \mathrm{~B}\end{array}$ & \\
\hline BARC10R & $\begin{array}{l}\text { GCGAGTTGGAATTATTTGAATTA } \\
\text { AACAAG }\end{array}$ & $\begin{array}{l}\text { GCGAGTTGGAATTATTTGAATTAA } \\
\text { ACAAG }\end{array}$ & & \\
\hline BARC12F18 & $\begin{array}{l}\text { CGACAGAGTGATCACCCAAATA } \\
\text { TAA }\end{array}$ & $\begin{array}{l}\text { ACGACGTTGTAAAACGACCGACAG } \\
\text { AGTGATCACCCAAATATAA }\end{array}$ & $\mathrm{Xbarc} 12,3 \mathrm{~A}$ & Pop2: 3A \\
\hline BARC12R & CATCGGTCTAATTGTCAATGTA & CATCGGTCTAATTGTCAATGTA & & \\
\hline BARC54F 18 & $\begin{array}{l}\text { GCGAACAGGAGGACAGAGGGCA } \\
\text { CGAGAG }\end{array}$ & $\begin{array}{l}\text { ACGACGTTGTAAAACGACGCGAAC } \\
\text { AGGAGGACAGAGGGCACGAGAG }\end{array}$ & $\begin{array}{l}\text { Xbarc54, 3A, } \\
6 \mathrm{D}\end{array}$ & Pop2: $3 \mathrm{~A}$ \\
\hline BARC54R & $\begin{array}{l}\text { GCGCTTTCCCACGTTCCATGTTT } \\
\text { CT }\end{array}$ & GCGCTTTCCCACGTTCCATGTTTCT & & \\
\hline BARC55F 18 & $\begin{array}{l}\text { GCGGTCAACACACTCCACTCCTC } \\
\text { TCTC }\end{array}$ & $\begin{array}{l}\text { ACGACGTTGTAAAACGACGCGGTC } \\
\text { AACACACTCCACTCСТCTCTC }\end{array}$ & $\begin{array}{l}\text { Xbarc55, 1B, } \\
2 \mathrm{~B}, 5 \mathrm{~B}\end{array}$ & \\
\hline BARC55R & $\begin{array}{l}\text { CGCTGCTCCCATTGCTCGCCGTT } \\
\text { A }\end{array}$ & CGCTGCTCCCATTGCTCGCCGTTA & & \\
\hline BARC57F18 & $\begin{array}{l}\text { GCGACCACCTCAGCCAACTTATT } \\
\text { ATGT }\end{array}$ & $\begin{array}{l}\text { ACGACGTTGTAAAACGACGCGACC } \\
\text { ACCTCAGCCAACTTATTATGT }\end{array}$ & $\mathrm{Xbarc57,3 \textrm {A }}$ & \\
\hline BAR0057R & $\begin{array}{l}\text { GCGGGGAGGCACATTCATAGGA } \\
\text { GT }\end{array}$ & GCGGGGAGGCACATTCATAGGAGT & & \\
\hline BARC59F 18 & $\begin{array}{l}\text { GCGTTGGCTAATCATCGTTCCTT } \\
\mathrm{C}\end{array}$ & $\begin{array}{l}\text { ACGACGTTGTAAAACGACGCGTTG } \\
\text { GCTAATCATCGTTCCTTC }\end{array}$ & $\begin{array}{l}\text { Xbarc59, 2D, } \\
5 \mathrm{~B}\end{array}$ & \\
\hline BARC59R & $\begin{array}{l}\text { AGCACCCTACCCAGCGTCAGTCA } \\
\text { AT }\end{array}$ & $\begin{array}{l}\text { AGCACCCTACCCAGCGTCAGTCAA } \\
\mathrm{T}\end{array}$ & & \\
\hline
\end{tabular}




\begin{tabular}{|c|c|c|c|c|}
\hline Primer & Sequence & DNA Sequence Tailed & $\begin{array}{c}\text { Locus/ } \\
\text { Putative } \\
\text { Chromosomes } \\
\text { as per Grain } \\
\text { genes } \\
\end{array}$ & $\begin{array}{c}\text { Putative } \\
\text { chromosome } \\
\text { (this study) }\end{array}$ \\
\hline BARC77F 18 & $\begin{array}{l}\text { GCGTATTCTCCCTCGTTTCCAAGT } \\
\text { CTG }\end{array}$ & $\begin{array}{l}\text { ACGACGTTGTAAAACGACGCGTAT } \\
\text { TCTCCCTCGTTTCCAAGTCTG }\end{array}$ & Xbarc77, 3B & Pop2: 3A \\
\hline BARC77R & GTGGGAATTTCTTGGGAGTCTGTA & GTGGGAATTTCTTGGGAGTCTGTA & & \\
\hline BARC105F18 & $\begin{array}{l}\text { CAGGAAGAAAAGGAAAGCATGC } \\
\text { GACAA }\end{array}$ & $\begin{array}{l}\text { ACGACGTTGTAAAACGACCAGGAA } \\
\text { GAAAAGGAAAGCATGCGACAA }\end{array}$ & $\begin{array}{l}\text { Xbarc105, 3A, } \\
7 \mathrm{~A}, 7 \mathrm{D}\end{array}$ & Pop2: $3 \mathrm{~A}$ \\
\hline BARC105R & GCGGTGTGGCAATAATTACTTTTT & GCGGTGTGGCAATAATTACTTTTT & & \\
\hline BARC31CF18 & GGGCGGCGCATGTGCACCTA & $\begin{array}{l}\text { ACGACGTTGTAAAACGACGGGCGG } \\
\text { CGCATGTGCACCTA }\end{array}$ & Xbarc310, 3A & \\
\hline BARC31CR & GCGTGGAAGCGACTAAATCAACT & GCGTGGAAGCGACTAAATCAACT & & \\
\hline BARC321F18 & TGCACTTCCCACAACACATC & $\begin{array}{l}\text { ACGACGTTGTAAAACGACTGCACT } \\
\text { TCCCACAACACATC }\end{array}$ & $\begin{array}{l}\text { Xbarc321, 3A, } \\
\text { 3D }\end{array}$ & \\
\hline BARC321R & TTGCCACGTAGGTGATTTATGA & TTGCCACGTAGGTGATTTATGA & & $\begin{array}{l}\text { Pop1: 3A; } \\
\text { Pop2: 3A }\end{array}$ \\
\hline CFA2193F 18 & ACATGTGATGTGCGGTCATT & $\begin{array}{l}\text { ACGACGTTGTAAAACGACACATGT } \\
\text { GATGTGCGGTCATT }\end{array}$ & Xcfa2193, 3A & \\
\hline CFA2193R & TCCTCAGAACCCCATTCTTG & TCCTCAGAACCCCATTCTTG & & \\
\hline DUP398F18 & CTGAGCCCTCTTTGCTATGC & $\begin{array}{l}\text { ACGACGTTGTAAAACGACCTGAGC } \\
\text { CCTCTTTGCTATGC }\end{array}$ & Xdup398, 2B & \\
\hline DUP398R & TCGGTGAGATTGAAAGGTCC & TCGGTGAGATTGAAAGGTCC & & \\
\hline CFD10F18 & CGTTCTATGACGTGTCATGCT & $\begin{array}{l}\text { ACGACGTTGTAAAACGACCGTTCT } \\
\text { ATGACGTGTCATGCT }\end{array}$ & $\begin{array}{l}\text { Xcfd10, 5A, } \\
5 B\end{array}$ & \\
\hline CFD10R & TCCATTTTCAAAAACACCCTG & TCCATTTTCAAAAACACCCTG & & $\begin{array}{l}\text { Pop2: } 3 \mathrm{~A} \\
\text { pop3:3A }\end{array}$ \\
\hline
\end{tabular}




\begin{tabular}{|c|c|c|c|c|}
\hline Primer & Sequence & DNA Sequence Tailed & $\begin{array}{l}\text { Locus/ } \\
\text { Putative } \\
\text { Chromosomes } \\
\text { as per Grain } \\
\text { genes }\end{array}$ & $\begin{array}{l}\text { Putative } \\
\text { chromosome } \\
\text { (this study) }\end{array}$ \\
\hline FBB0335F18 & AACAGCTATGACCATG & $\begin{array}{l}\text { ACGACGTTGTAAAACGACAACAGC } \\
\text { TATGACCATG }\end{array}$ & FBB0335 & $\begin{array}{l}\text { Pop1: 3A; } \\
\text { Pop2: 3A }\end{array}$ \\
\hline FBB0335R & GTAAAACGACGGCCAGT & GTAAAACGACGGCCAGT & & \\
\hline GWM132F 18 & TACCAAATCGAAACACATCAGG & $\begin{array}{l}\text { ACGACGTTGTAAAACGACTACCAA } \\
\text { ATCGAAACACATCAGG }\end{array}$ & $\begin{array}{l}\text { Xgwm132, } \\
6 \mathrm{~B}, 6 \mathrm{D}\end{array}$ & \\
\hline GWM132R & CATATCAAGGTCTCCTTCCCC & CATATCAAGGTCTCCTTCCCC & & \\
\hline GWM155F 18 & СААТСАТТТСССССТССС & $\begin{array}{l}\text { ACGACGTTGTAAAACGACCAATCA } \\
\text { TTTCCCCCTCCC }\end{array}$ & $\begin{array}{l}\text { Xgwm155, } \\
1 \mathrm{D}, 3 \mathrm{~A}\end{array}$ & \\
\hline GWM155R & AATCATTGGAAATCCATATGCC & AATCATTGGAAATCCATATGCC & & \\
\hline GWM261F18 & СTCCCTGTACGCCTAAGGC & $\begin{array}{l}\text { ACGACGTTGTAAAACGACCTCCCT } \\
\text { GTACGCCTAAGGC }\end{array}$ & Xgwm261, 2D & \\
\hline GWM261R & CTCGCGCTACTAGCCATTG & CTCGCGCTACTAGCCATTG & & \\
\hline GWM371F18 & GACCAAGATATTCAAACTGGCC & $\begin{array}{l}\text { ACGACGTTGTAAAACGACGACCAA } \\
\text { GATATTCAAACTGGCC }\end{array}$ & $\begin{array}{l}\text { Xgwm371, } \\
5 \mathrm{~B}, 5 \mathrm{D}\end{array}$ & \\
\hline GWM371R & AGCTCAGCTTGCTTGGTACC & AGCTCAGCTTGCTTGGTACC & & \\
\hline GWM429F 18 & TTGTACATTAAGTTCCCATTA & $\begin{array}{l}\text { ACGACGTTGTAAAACGACTTGTAC } \\
\text { ATTAAGTTCCCATTA }\end{array}$ & Xgwm429, 2B & \\
\hline GWM429R & TTTAAGGACCTACATGACAC & TTTAAGGACCTACATGACAC & & \\
\hline GWM494F 18 & ATTGAACAGGAAGACATCAGGG & $\begin{array}{l}\text { ACGACGTTGTAAAACGACATTGAA } \\
\text { CAGGAAGACATCAGGG }\end{array}$ & $\begin{array}{l}\text { Xgwm494, } \\
3 \mathrm{~A}, 4 \mathrm{~A}\end{array}$ & \\
\hline GWM494R & TTCCTGGAGCTGTCTGGC & TTCCTGGAGCTGTCTGGC & & \\
\hline MST0101F18 & CCACCATGAAGACCTTCCTC & $\begin{array}{l}\text { ACGACGTTGTAAAACGACCCACCA } \\
\text { TGAAGACCTTCCTC }\end{array}$ & MST0101, 7D & $\begin{array}{l}\text { Pop1: 3A; } \\
\text { Pop2: 3A }\end{array}$ \\
\hline MST0101R & ACCTTGCATGGGTTTAGCTG & ACCTTGCATGGGTTTAGCTG & & \\
\hline WMC48F18 & GAGGGTTCTGAAATGTTTTGCC & $\begin{array}{l}\text { ACGACGTTGTAAAACGACGAGGGT } \\
\text { TCTGAAATGTTTTGCC }\end{array}$ & $\begin{array}{l}\text { Xwmc48, 4A, } \\
\text { 4B }\end{array}$ & \\
\hline WMC48R & ACGTGCTAGGGAGGTATCTTGC & ACGTGCTAGGGAGGTATCTTGC & & \\
\hline
\end{tabular}




\begin{tabular}{|c|c|c|c|c|}
\hline Primer & Sequence & DNA Sequence Tailed & $\begin{array}{c}\text { Locus/ } \\
\text { Putative } \\
\text { Chromosomes } \\
\text { as per Grain } \\
\text { genes }\end{array}$ & $\begin{array}{c}\text { Putative } \\
\text { chromosome } \\
\text { (this study) }\end{array}$ \\
\hline WMC59F & $\begin{array}{l}\text { ACGACGTTGTAAAACGACTCATT } \\
\text { CGTTGCAGATACACCAC }\end{array}$ & $\begin{array}{l}\text { ACGACGTTGTAAAACGACTCATTC } \\
\text { GTTGCAGATACACCAC }\end{array}$ & Xwmc59, 1A & \\
\hline WMC59R & TCAATGCCCTTGTTTCTGACCT & TCATTCGTTGCAGATACACCAC & & \\
\hline WMC96F18 & TAGCAGCCATGCTTAGCATCAA & $\begin{array}{l}\text { ACGACGTTGTAAAACGACTAGCAG } \\
\text { CCATGCTTAGCATCAA }\end{array}$ & $\begin{array}{l}\text { Xwmc96, 3A, } \\
4 \mathrm{~A}, 5 \mathrm{~A}, 5 \mathrm{D}, \\
6 \mathrm{~A}, 7 \mathrm{~A}\end{array}$ & Pop2:3A \\
\hline WMC96R & GTTTCAGTCTTTCACGAACACG & GTTTCAGTCTTTCACGAACACG & & \\
\hline WMC307F 18 & GTTTGAAGACCAAGCTCCTCCT & $\begin{array}{l}\text { ACGACGTTGTAAAACGACGTTTGA } \\
\text { AGACCAAGCTCCTCCT }\end{array}$ & Xwmc307, 3B & \\
\hline WMC307R & ACCATAACCTCTCAAGAACCCA & ACCATAACCTCTCAAGAACCCA & & \\
\hline WMC349F 18 & ACACACACTCGATCGCAC & $\begin{array}{l}\text { ACGACGTTGTAAAACGACACACAC } \\
\text { ACTCGATCGCAC }\end{array}$ & Xwmc349, 4B & \\
\hline WMC349R & GCAGTTGATCATCAAAACACA & GCAGTTGATCATCAAAACACA & & Pop2:3A \\
\hline WMC428F18 & TTAATCCTAGCCGTCCCTTTTT & $\begin{array}{l}\text { ACGACGTTGTAAAACGACTTAATC } \\
\text { CTAGCCGTCCCTTTTT }\end{array}$ & Xwmc428, 3A & \\
\hline WMC428R & CGACCTTCGTTGGTTATTTGTG & CGACCTTCGTTGGTTATTTGTG & & $\begin{array}{l}\text { Pop1: 3A; } \\
\text { Pop2:3A }\end{array}$ \\
\hline WMC552F 18 & ACTAAGGAGTGTGAGGGCTGTG & $\begin{array}{l}\text { ACGACGTTGTAAAACGACACTAAG } \\
\text { GAGTGTGAGGGCTGTG }\end{array}$ & Xwmc552, 3D & \\
\hline WMC552R & CTCTCGCGCTATAAAAGAAGGA & CTCTCGCGCTATAAAAGAAGGA & & \\
\hline WMC594F 18 & CCCCTCACTGCCG & $\begin{array}{l}\text { ACGACGTTGTAAAACGACCCCCTC } \\
\text { ACTGCCG }\end{array}$ & Xwmc594, 3A & \\
\hline WMC594R & ATATCCATATAGTACTCGCAC & ATATCCATATAGTACTCGCAC & & Pop1: 2B \\
\hline WMS319F18 & GGTTGCTGTACAAGTGTTCACG & $\begin{array}{l}\text { ACGACGTTGTAAAACGACGGTTGC } \\
\text { TGTACAAGTGTTCACG }\end{array}$ & $\begin{array}{l}\text { Xwmc319, 2B, } \\
7 \mathrm{~A}\end{array}$ & \\
\hline WMS319R & CGGGTGCTGTGTGTAATGAC & CGGGTGCTGTGTGTAATGAC & & $\begin{array}{l}\text { Pop1: 2B; } \\
\text { Pop3: 2B or } \\
\text { 5A, 5B }\end{array}$ \\
\hline
\end{tabular}




\begin{tabular}{lllll}
\hline Primer & Sequence & DNA Sequence Tailed & $\begin{array}{l}\text { Locus/ } \\
\text { Putative } \\
\text { Chromosomes } \\
\text { as per Grain } \\
\text { genes }\end{array}$ & $\begin{array}{l}\text { Putative } \\
\text { chromosome } \\
\text { (this study) }\end{array}$ \\
\hline WMS429F18 & TTGTACATTAAGTTCCCATTA & $\begin{array}{l}\text { ACGACGTTGTAAAACGACTTGTAC } \\
\text { ATTAAGTCCATTA }\end{array}$ & Xwms429, 2B \\
WMS429R & TTTAAGGACCTACATGACAC & TTTAAGGACCTACATGACAC & \\
\hline
\end{tabular}

